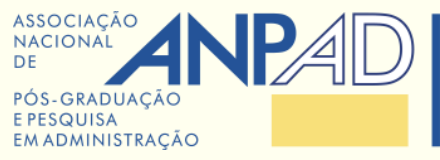

POS-GRAD

EMADMINISTRAÇÃO
https://bar.anpad.org.br
BAR - Brazilian Administration Review
Vol. 17, No. 3, Art. 1, e180128, 2020
https://doi.org/10.1590/1807-7692bar2020180128

(c) $\mathrm{BY}$
BAR

Brazilian

Administration

Review

Research Article

\title{
Country Brand Equity: The Role of Image and Reputation
}

Fabiana Gondim Mariutti ${ }^{1,2}$ Janaina de Moura Engracia Giraldi ${ }^{1}$

${ }^{1}$ Universidade de São Paulo, Ribeirão Preto, SP, Brazil

${ }^{2}$ Universidade Positivo, Curitiba, PR, Brazil

Received 05 November 2018. This paper was with the authors for two revisions. Accepted 9 July 2020. First published online 3 August 2020.

Editor-in-chief: Carlo Gabriel Porto Bellini (D) (Universidade Federal da Paraíba, João Pessoa, PB, Brazil)

Associate editor: Dinorá Eliete Floriani (ID) (Universidade do Vale do Itajaí, Itajaí, SC, Brazil)

Reviewers: Giovanna Magnani (ID) (University of Pavia, Italy) and an anonymous reviewer

Editorial assistants: Kler Godoy and Simone Rafael (ANPAD, Maringá, PR, Brazil) 


\section{ABSTRACT}

Country brand equity (CBE) is expanding in theory and in practice; however, little has been published on its conceptualization. By incorporating 'reputation' into the place brand equity construct at a country level, we provide a theoretical multidimensional framework for CBE. Seventeen interviews with international researchers were undertaken for theory building. A seven-dimensional CBE framework was developed according to the interpretations of two constructs - country brand reputation ('share of experience') and country brand image ('share of mind') - along with country brand associations, country brand awareness, country brand loyalty, country brand perceived quality, and channel relationships. We conclude by outlining potential further research avenues and implications for managerial practice. These contributions may guide policymakers, government officials, executives, and scholars in maximizing the value of a place brand (e.g., country, region, or city) by focusing on 'reputation' as an added (qualitative and/or quantitative) construct. This study may also inspire insights into joint efforts of public and private strategies and actions on economic performance, consumer welfare, and business decisions for national prosperity.

Keywords: brand equity; brand associations; image; reputation; place brand equity

JEL code: M16 


\section{INTRODUCTION}

Within the setting of international business, country branding has become necessary to build, manage, and monitor the value of the brand at this stage of the global development of branding (Steenkamp, 2017), because of the strategic function of country branding for any country's competitiveness (Foroudi, Gupta, Kitchen, Foroudi, \& Nguyen, 2016). Historically, branding of place has been considered a robust marketing research domain in academia (Bastos \& Levy, 2012; Warnaby \& Medway, 2013) since the earliest theoretical concepts to support strategies in positioning, advertising, communication, and sales (Kotler \& Levy, 1969), which provided the onto-epistemological starting point for place marketing and place branding (country, region, or city) as a core interest-context unit of analysis. Thus, Keller (1998, p. 19) observed that "the brand name is relatively fixed by the actual name of the location," which is relevant when considering the branding of a geographical location (such as a city, region, or country). Indeed, any of these geographic-spatial places holds multifaceted tangible and intangible features that may influence place reputation, due to the many stakeholders and communication channels involved (Warnaby \& Medway, 2013). Therefore, sustaining CBE for the long term requires strategic brand management (Kapferer, 1992; Pappu, Quester \& Cooksey, 2006). CBE, as a conceptual extension of the theory of brand equity, refers to the value of a country's brand (Zeugner-Roth, Diamantopoulos, \& Montesinos, 2008) and acts as an outcome of referred value (Davcik, Silva, $\&$ Hair, 2015). Thus, the country brand can be one of the most valuable intangible assets of a country, for brand equity represents a 'relational' type of market-based intangible asset (Veloutsou, Christodoulides, \& Chernatony, 2013).

In this scenario, we identify an ongoing debate among scholars regarding the conceptualization of CBE. Specifically, CBE has gained broad attention since 2000 and has gradually advanced in both the theoretical and methodological levels - as has the significance of a country's brand per se (Giraldi, 2016; Papadopoulos \& Heslop, 2002; Papadopoulos \& Hamzaoui-Essoussi, 2015). Moreover, just as the marketable scope of the country brand has expanded, so has academic interest. However, research on CBE remains in its infancy in the marketing literature (Bose, Roy, Alwi, \& Nguyen, 2020; Pappu \& Quester, 2010; Zeugner-Roth, Diamantopoulos, \& Montesinos, 2008). Most CBE research conducted thus far has been quantitative in nature (Bose et al., 2020; Mariutti \& Giraldi, 2019; Pappu et al., 2006; Pappu \& Quester, 2010; Zenker, 2014; ZeugnerRoth et al., 2008). These past studies have defined CBE in a consolidated deductive-hypothetic approach for each of its stakeholder groups, markets, or country of origin. In this regard, we discern a crucial gap in the literature regarding perceptual components of the conceptualization of country brand equity (CBE), and, to date, researchers' and marketers' interpretations have not investigated the conceptual distinctions between the image of a country and its reputation. Studies on CBE have neglected the brand reputation construct, forgetting that image per se is part of the reputation (de Chernatony, 1999; Jurisic \& Azevedo, 2011; Pappu \& Quester, 2010). Therefore, we distinguish and disclose them and their interrelationships with CBE due to the paucity of research regarding the roles of image and reputation as constructs of brand equity (Chatzipanagiotou, Veloutsou, \& Christodoulides, 2016; Foroudi et al., 2016; Papadopoulos \& Heslop, 2002).
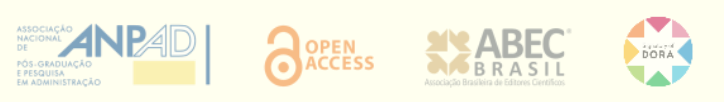
We emphasize that 'reputation' constitutes a significant construct of brand equity because it denotes the overarching concept of the 'image' construct, in accordance with the previous literature, which has interpreted brand image as part of brand reputation (de Chernatony, 1999). In the interim, country image (CI) has been commonly understood as a multidimensional construct (Papadopoulos \& Heslop, 2002; Roth \& Diamantopoulos, 2009), that is, a generic construct consisting of generalized images that do not necessarily encompass products (Roth \& Diamantopoulos, 2009). Consequently, this study seeks to shift our view of CI in a principled way, by adding its conceptual findings to the literature and practice concerning the international business field.

The purpose of this study is to provide a conceptual framework for our inquiry into CBE by incorporating 'reputation' into the brand equity conceptualization at a country level (Suddaby, 2010). We acknowledged CBE by applying two interpretative conducts due to the complex knowledge domain of country brand equity. First, we deductively explored this topic from the existing literature review; second, we inductively unpacked the concept of CBE using qualitative data from international researchers to build a qualitative counterpart of theoretical knowledge for research in business studies. Thus, the rationale for this study emerged from the literature review, which led to the following research question of this exploratory study: 'How are country image and country reputation in the context of country brand conceptualized in extant research?' We argue that CBE is comprised of (a) the image of a country (region or city); (b) its reputation, through development based on a dynamic and forward-looking approach (Veloutsou \& Guzmán, 2017), and (c) an improved combination of components related to the value of a country (Papadopoulos \& Heslop, 2003). Hence, our contributions are twofold: (a) in terms of the literature, as this study assesses the influence of reputation on brand equity, and (b) to practice, as this study also recognizes its potential impact on international business strategies worldwide. To this end, we encourage not only business researchers but also interested scholars and practitioners in other fields to advance the understanding of the multifaceted implications of a country's status quo.

\section{LITERATURE REVIEW}

\section{Brand equity}

Aaker (1991, 1992), as the founder of the first consumer-based brand equity (CBBE) model, focused on the conceptualization of brand equity through the perceptual and behavioral components mentioned earlier; his significant work is detailed and considerable, but does not consider brand image or brand reputation. That said, Aaker does hint at brand reputation being an intangible attribute of brand (Aaker, 1991). For Keller (1993, 1998), brand equity consists of two main perceptual components, that is, brand knowledge (recall and recognition) and brand image (brand associations). Moreover, as with the CBBE perspective, brand reputation was not taken into consideration when examining brand equity.

Notwithstanding its early conceptual origins, research on brand equity did not emerge as an issue in marketing until the twenty-first century. Yoo and Donthu (2001) developed the first 
measurement model of CBBE; it was a three-dimensional perceptual construct for measuring brand equity consisting of brand loyalty, perceived quality, and brand awareness/associations (as a single dimension). The Yoo and Donthu model was based on the conceptualizations of Aaker (1991) and Keller (1993). In sum, brand equity is the total value added to the product by its brand name (Yoo \& Donthu, 2001). Although their research represented an advance in terms of the dimensions of brand equity and its interrelationships, brand association and brand awareness are treated jointly, and brand reputation was not measured. Since then, a large body of research investigating brand equity regarding products and services has emerged. Undeniably, brand equity currently holds a well-recognized position in marketing theory; yet after almost three decades of research on brand equity (Davcik, Silva, \& Hair, 2015), there is little agreement on the concept of brand equity (Veloutsou et al., 2013) and place brand equity (Zavattaro, Daspit, \& Adams, 2015; Zenker, 2014).

Grounded in the conceptual fundamentals of Aaker's model (1991) and based on the consumer perspective and Keller's conceptualizations of brand equity, the element 'brand associations' was designated by us, thereby narrowing this study's framework. Along the same lines, Yoo and Donthu (2001) and Pappu et al (2006) studied a conceptualization of brand equity whereby brand associations were empirically acknowledged. Additionally, Keller argued that brand associations "may be created by linking the brand to another node or information in memory that conveys meaning to consumers" (1998, p. 74). Furthermore, place brand associations can influence brand image favorability when related to place brand equity (Bose et al., 2020; Zenker, 2014).

\section{Country brand equity}

Despite the prevalence of brand equity studies in marketing and the increasing numbers of studies of $\mathrm{CBE}$ in international business, the main publications have neglected the conceptualization of CBE beyond the classical constructs. Scholars' attempts to define CBE have clarified the debate by stating that the concept refers to "the value that may be embedded in perceptions by various target markets about the country, and the ways in which these perceptions may be used to advance its interests and those of its constituents" (Papadopoulos \& Heslop, 2002, p. 285). Later, Papadopoulos and Heslop (2002) re-phrased Aaker's (1991) ideas by arguing that CBE suggests "a set of country assets and liabilities linked to a country, its name and symbols, that add to or subtract from the value provided by the country's outputs to its various internal and external publics" (Papadopoulos \& Heslop, 2002, p. 581). CBE is a multidimensional model based on several proposed measurements (Papadopoulos \& Heslop, 2002, 2003; Pappu et al., 2006; Pappu \& Quester, 2010; Zeugner-Roth et al., 2008); however, the conceptualization of $\mathrm{CBE}$ has not been treated as the complex phenomenon that it is, one that demands new understandings and requiring additional knowledge through a qualitative approach.

Two influential quantitative studies in the CBE literature were derived from these classical conceptualizations (Aaker, 1991, 1992; Keller, 1993) from a consumer perspective. Additionally, Zeugner-Roth et al. (2008), who advanced a CBE model that has been used in the literature, define $\mathrm{CBE}$ as "the value-added brought forth by the association of a product or brand with a
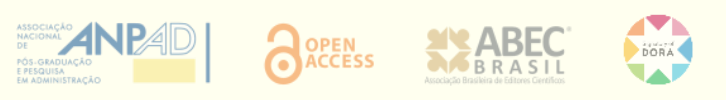
given country name, as perceived by the individual consumer" (p. 594). Their model is based on Yoo and Donthu's (2001) brand equity scale, in which a CBE scale is developed joining the (home) $\mathrm{CI}$ and product preferences with CBE as an intervening variable (Zeugner-Roth et al., 2008), using two variables: overall CI (description of the people and aspirations of the country) and overall CBE (country brand loyalty, country brand perceived quality, and country brand awareness/associations). Their research investigated consumer (Spanish university students) preferences towards products from the USA. As the main findings, CBE was influenced by CI perceptions and positively impacted product preferences, although the latter were not directly influenced by CI perceptions (Zeugner-Roth et al., 2008). Another important work, a model by Pappu and Quester (2010), measures, from a consumer perspective, country equity in terms of the value endowed by a country onto products originating from that country. For them, country equity refers to "the value endowed by the name of the country onto a product" (Pappu \& Quester, 2010, p. 2). In developing a differentiated model, they applied five dimensions: macrocountry image, micro-country image, perceived quality, country loyalty, and country awareness. Their results show that consumers have associations towards countries both at the country level and at the product level (Pappu \& Quester, 2010). Nevertheless, although both multidimensional models advanced the ability to measure and successfully investigated CBE in specific markets, brand reputation was absent from their CBE scales. This gap leads to the motivation for our study to focus on brand reputation. Moreover, CBE has also been hypothesized using country-of-origin (COO) associations, as suggested by Kotler, Haider, and Rein (1993), and no satisfactory conclusion on the complexity of the conceptualization of CBE was found. However, we contend that core constructs, such as $\mathrm{CI}$ and country reputation (CR), are part of and contribute to $\mathrm{CBE}$ in terms of involving country brand associations. The outcomes of the study of Veloutsou et al. (2013) on brand equity categories of measures and variables classified brand associations as a variable related to consumer understanding of brand characteristics, and reputation as a variable related to consumer evaluation of the brand. The present work follows this rationale for developing our model of CBE. A further challenge for CBE is to theoretically develop these two views. Furthermore, Chatzipanagiotou et al. (2016) consider brand reputation to be its 'overall value,' that is, a vital part of the brand that largely depends on brand associations.

\section{Country image and reputation}

Considering current advancements in CBE, the equity of a country encompasses the CI, (Pappu et al., 2006; Zeugner-Roth et al., 2008), which has been a topic of interest for country-of-origin researchers for several decades (Pappu \& Quester, 2010). CI studies primarily focused on a country's products in the mid-1960s (Giraldi, 2016). Later, the role and importance of CI became clear for attracting foreign investment, promoting a country's exports, protecting domestic markets from imports, and enticing international mega-events to promote the national image through articulating strategies and policies (Papadopoulos \& Heslop, 2003). However, most studies on $\mathrm{CI}$ are produced in the disciplines of international business or international marketing, while country brand studies (including CR) are found not only in these two disciplines, but also in media studies, communication, public relations, public diplomacy, international relations, and place branding. 
Given that "constructs are the foundation of theory" (Suddaby, 2010, p. 346), the present study seeks to expand knowledge on the image and the reputation of a country in support of the country-brand-equity construct. More recently, these differentiated avenues of CI research have led to the development of CR as an progressing theoretical-scheme (Foroudi et al., 2016; Foroudi, Jin, Gupta, Foroudi \& Kitchen, 2018; Mariutti, 2017; Passow, Fehlmann, \& Grahlow, 2005), resulting from indeterminate theories that are likely to affect country brand equity. Since then, the broad use of the term CI has sometimes been equated with CR and, in the recent literature, the reputation of a country is often related to the term CI (Kotler \& Gertner, 2002). The international reputation of a country is improved by aligning innovation with strategies in which countries endeavor to compete in the global economy. Today, countries must not only manage their reputations but also increase their competitiveness to develop and promote their identities. Passow, Fehlmann, and Grahlow (2005) noted that CR is a strategic concept centered on longterm impressions that are constructed by the images and actions of a country. Therefore, while the image of a country is perceived by external stakeholders, the reputation of a country involves both internal and external stakeholders (Passow et al., 2005). Moreover, brand reputation functions as a long-term and overall evaluation (Selnes, 1993) that requires consistency. In the present work, we follow Selnes' description regarding country brand. Brand image, on the other hand, refers to current perceptions and is continually changing according to shifts in brand reputation, which is more stable (de Chernatony, 1999; Kapferer, 1992). Nevertheless, a reasonable attempt to distinguish between the terms 'brand imag' and 'brand reputation' have been made (de Chernatony, 1999); for instance, brand reputation is a more powerful concept than brand image (de Chernatony, 1999).

Reputation is a value-based construct and a time-based construct based on the relationship between the organization and the multiple stakeholders (de Chernatony, 1999; Kapferer, 1992). Brand image enhances brand reputation, consistent with the image of a place (country, region, or city), which is also an element of the brand (Aaker, 1992; de Chernatony, 1999; Fill, 2013). It has been argued that brand reputation, which is a more powerful construct than brand image, contains the latter (de Chernatony, 1999) because reputation portrays the internal and external assessment of multiple stakeholders. Brand reputation is also defined as the perception of quality associated with the name of the brand (Selnes, 1993), evoked by associations with the product, service, or place. When forming brand perceptions, people draw on many sources at different points in time, resulting in a reputation (de Chernatony, 1999; Fill, 2013; Kapferer, 1992). Furthermore, Kapferer (1992, p. 30) noted that "changes in reputation affect all stakeholders" of a company, which may also be said of a country, which is an exception to the multiplicity of internal and external stakeholders and the diversity of dimensions of a country's brand. Equally, based on one of the brand equity theories, stakeholder perspectives (Davcik, Silva, \& Hair, 2015), brand associations (Chatzipanagiotou et al., 2016), and brand reputation (Foroudi et al., 2016) are relevant to the conceptualization of country brand equity. Indeed, in discussing image and reputation in place branding, the role of place associations underscores its central significance (Foroudi et al., 2016).

Thus, joining in the calls made by previous authors and based on the evidence reviewed throughout this debate, we propose this comprehensive qualitative study to relate $\mathrm{CI}$ and $\mathrm{CR}$ to

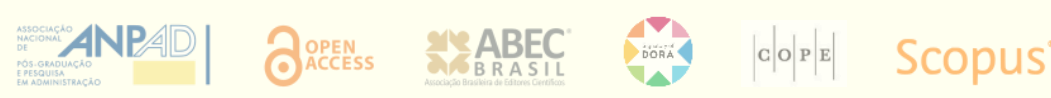


the conceptualization of CBE. Even though these two constructs theoretically overlap, that is, CI is attached to $\mathrm{CR}$, they are theoretically detached in nature and convey slightly different meanings and distinctive understandings; both, however, are theoretically linked to CBE. Therefore, within the scope of marketing and branding, these two separate branding constructs cannot be considered synonymous. However, there can be no doubt that both are closely and theoretically interlinked with each other when investigating country brand equity.

\section{RESEARCH DESIGN}

A qualitative approach to place brand studies was recommended by previous researchers (Foroudi et al., 2016) and place brand equity (Zavattaro et al., 2015) for theory building (Yadav, 2014). Seventeen semi-structured interviews with international researchers were conducted during the summer of 2017 (Appendix 1). An individual in-depth interview was adopted to reveal considerations on the topic in light of the researchers' professional positions and expertise (Flick, 2014). Purposive sampling is appropriate for providing robust data for this exploratory research (Flick, 2014). Sixteen interviews were face-to-face, and one interview was done via Skype. Before collecting this primary data, ethical approval was obtained using a consent form.

\section{Data collection}

Qualitative data are useful for characterizing constructs and obtaining detailed evidence and a greater understanding of CBE (Flick, 2014). Thus, novel perspectives and rational answers are significant advantages of personal interviews. This unique dataset represents a key strength of researching such an important phenomenon and warrants examination. In line with the recommendations of Yadav (2014) on theory development, we attempted to fill the current research gap on place brand equity with a comprehensive analysis aligned with the most significant literature on the topic. Furthermore, given the under-explored albeit interrelated themes in academic and executive settings, this research design supported robust outcomes. The sessions lasted between 20 minutes and one hour and were held at the interviewees' university workplaces. Qualitative data were gathered using digital audio recording (app eXtra Voice Recorder by Xwavesoft) and notes taken during and after (by memo) each interview by the first author (interviewer).

To produce an accurate and complete synthesis for the data collection instrument, the main topics comprising the discussion guide were adapted from the literature review and oriented by our research questions: Considering the value of country brands, what is your opinion of the statement, 'each time the name of a country is mentioned, there is an opportunity to add to or subtract value from its country brand equity' (Aaker, 1991; Kotler \& Gertner, 2002; Papadopoulos \& Heslop, 2002)? Moving on to both Aaker's CBBE model (1991) and Keller's concepts (1993), as they prevail in the literature - adjusted to or tested with a country context, what is your consideration regarding these theoretical and methodological transpositions to country brand equity? Based on your understanding, what are the differences or similarities between the terms 'country image' and 'country reputation' in a country-brand context? 


\section{Data analysis}

To conceptualize CBE by incorporating 'reputation' and 'image', it was required to apply two interpretative approaches by adopting qualitative counterpart-orientated research. The first approach has deductively uncovered CBE, along with both constructs, from the existing literature review; the second approach has inductively explored $\mathrm{CBE}$ using qualitative data from interviews for the construction of its conceptualization per se. Moving back and forth between the empirical evidence and the literature enabled us to build theoretical knowledge by mutually accumulating and realistically capturing the authentic process by which theorizing occurs. To begin this process, identifiable subjects and conceptual patterns were thematically listed from the interview data, focusing on contextualizing them in relation to the existing literature by applying thematic analysis, which is compatible with various theoretical conceptualizations (Flick, 2014). By refining the data using a highly inductive approach, the main theoretic insights emerged from the gathered empirical material. Nevertheless, identifying key patterns that match data with theory was fundamental to build conceptual linkages between both. Moreover, the rich qualitative evidence supported and expanded our previous understanding of brand equity at a country level in terms of its structure and mutual importance to CBE. The validity and reliability of this research is due to the organized alignment between theory and data (Flick, 2014).

Thus, the data analysis was grounded in the interviewees' replies and relevant full quotes, as uttered by the participants and developed by the discussion (Flick, 2014; Hair, Wolfinbarger, Ortinau, \& Bush, 2010). Regarding the procedures employed for data analyses, coding procedures supported the exploration of the participants' viewpoints on the topic under study to answer the research question and advance the theory (Flick, 2014). Following the transcription of the interviews by the first author (interviewer), the data were analyzed using a thematic-based comparison for each question, considering the conceptualization of the CBE (Flick, 2014), and included theories in the fields of brand equity and country brand, considering the two related constructs of brand equity (Papadopoulos \& Heslop, 2003), that is, brand reputation and brand image. Both authors were involved in the data analysis to maximize objectivity. To begin the process, the first author prearranged the dataset using an Excel spreadsheet for each question of the interview's script and proposed the specific themes guided by the research question. The second author, the independent coder, was familiar with CBE but was not involved in the data collection. The criteria for coding involved theoretical identifications with the research question in light of branding theories and previous studies (Hair et al., 2010). We then coded each theme according to (a) the conceptual similarities and differences between brand image and brand reputation, (b) the conceptualization of CBE regarding comparisons between $\mathrm{CI}$ and $\mathrm{CR}$, and (c) insightful recommendations on $\mathrm{CBE}$ research. After these procedures, to compare the interviewees' replies, systematic extraction of the related theme from each interview was undertaken. By coding the themes to conceptualize CBE, from this unique data set, we analyzed the interrelationships with $\mathrm{CI}$ and $\mathrm{CR}$, interpretations from the reviewed theoretical definitions, the identification of these two constructs' roles, and the relationships of conceptual linkages that were considered by differentiating and integrating the constructs (Yadav, 2014). 


\section{DISCUSSION}

This study explored the understandings and interpretations of CBE based on a review of the related literature and qualitative analysis (Flick, 2014). These findings indicate the conceptualization of CBE by presenting a new framework based on the literature and the analyzed sample dataset completed with verbal quotes.

\section{The conceptualization of country brand equity}

Regarding the examination of the responses of the first question of the interview script, most of the interviewees confirmed that the conceptualization of CBE is a complex (Chatzipanagiotou et al., 2016; Zenker, 2014) yet current and rewarding topic (Bose et al., 2020; Pappu \& Quester, 2010; Zeugner-Roth et al., 2008). For this sample of authorities, Aaker's CBBE model (1991) and Keller's concepts $(1993,1998)$ prevail in the brand equity literature and should be adjusted or tested through their application to studies regarding place brand equity. These seminal models, long-applied in brand equity, should be theoretically and methodologically re-designed, as several reworkings are required in terms of adding dimensions and indicators to advance the knowledge of brand equity (Veloutsou \& Guzmán, 2017) for a place setting. Nevertheless, seven interviewees (E3, E4, E5, E7, E9, E10, and E17) emphasized the difficulty of transferring these traditional principles to a CBE framework.

Similarly, E11 said the challenge to tackle a country brand's complexity is already recognized in the literature (Chatzipanagiotou et al., 2016; Mariutti, 2017; Pappu \& Quester, 2010; Zenker, 2014):

"It is very complex for the country context, due to the historical, social, and cultural dimensions, very difficult... There is a danger in the country brand concept if it is oversimplified from a very complex entity."

One interviewee, E1, claimed that adapting the models to the stakeholder's group is fundamental, a view consistent with previous authors in the literature review:

"How country brand manages its symbolic capital will vary with its respective public audience. Management needs to be complex and layered, not simply a matter of adding to or subtracting from but working with it."

These outcomes, and several others, sustain our coding process and reflect the authors' agreedupon patterns for the development of our archetypal structure. Vis-à-vis the conceptual considerations of $\mathrm{CI}$ and country reputation, the interviewees expressed their understanding of them in relation to country brand equity, as summarized in Table 1. 
Table 1

Quotes from the interviews' dataset

\begin{tabular}{ll}
\hline Image & Reputation \\
\hline "There is a reasonably clear cut between these two concepts..." by E7
\end{tabular}

"There is a timing issue between them... They are close in meaning and similar linguistically" by E4

"Reputation is a variable in branding, marketing. Like branding image, supposedly, it is people's perception of a country image; supposedly, reputation should be an element. To me, it is not included in any brand image-related model" by E7

"Well-defined" by E7

"The outlook of a country" by E10

"People's perceptions as the overall perception of the country" by E8, agreed by E7, E10

"Superficial" by E9 and E13

"Pictorial" by E3, E5, and E9

"There is an interplay on the brand identity and brand image" by E8

"Country image is portrayed by the country, result of the media or activities of the particular country" by E11

"...It is perhaps a distilled version of reputation, as simplified pictures alluded to different aspects of reputation. Image presents some superficial representation not always from events" by E9

"Image is related to country of origin associations that we make with the name of a country when attached to a product versus..." by E12

"Country image is instantaneous, is always evolving, and it is easier to be changed (in a short term)" by E14

"Image means the real status of a country" by E15

"Vaguer, quite often associated to country reputation" by E17

"Country reputation captures the image while country brand is the core construct communicating the country" by E16

"Both can be measured" by E6

\begin{abstract}
"Image is different, sure it is impacted by reputation" by E2
"It is related to attitude towards the country as the overall evaluation" by E8
\end{abstract}

"Country reputation is related to attitude towards the country as the overall evaluation" by E8

"Reputation is dense, stronger, more serious, it is also more difficult to be changed" by E13

"It is a method of communication; is the means to understand the image, just the means (way)" by E10

"Country reputation is wider, it functions not only from media representativeness, is what we hear from family, friends... more comparative due to the good or bad reputation, is relative to the positive and negative associations" by E11

"Reputation is a greater knowledge basis. It suggests to me that it is more based on what it is happening, events, actions. It tends to be remitted to the news, experiences not visual. 'What do I know beyond pictures?'” by E9

"... Reputation is much more related to how much do we trust or appreciate positively or negatively doing business with a country or people or businesses from a country" by E12.

"Country reputation has to do with the result of the accumulative assets in a long term, involves historical and physical properties" by E14

"Image generates strength for building reputation" by E15

"Reputation is clearer, more philosophical level" by E17

Based on the demands and critiques of the specialist interviewees, we elucidate the dimensions that emerged from the empirical method by debating the main inquiries of the interview script, as follows:

\section{Relating the value of a country name to its country brand equity}

Most of the sample indicated the importance of the consistent attachment of the name of a country to CBE (Aaker, 1991, 1992; Keller, 1998), assets, symbols (Aaker, 1991), or its products (Aaker, 1991; Pappu \& Quester, 2010; Yoo \& Donthu, 2001; Zeugner-Roth et al., 2008). Furthermore, this attachment is also linked to the conceptual basis that brand reputation is 
delineated via perceptions of quality associated with the name of the (country) brand (Selnes, 1993). The sample also highlighted the importance of the stakeholders.

Likewise, as stressed by E11,

"Country brand is perceived in the eyes of the beholder. CBE is not understood in isolation; it is an incremental process."

Importantly, the diversity of stakeholders was reasoned as an essential issue in managing country brand equity; for instance, E13 said,

"it is fundamental to analyze country image and its brand associations by different stakeholders: internal (residents and politicians), media, other sectors."

As pointed out by E1,

"you can portray an image (positive or negative) using reputation management with the right investment and brand values. That is what counts when it comes to engaging the stakeholders with your brand."

E2 recalls that, "for me, brand is related to the audience, and the audiences of a country varies."

Another key quote on strategies to adding value to a country's brand was by E9:

"Pinpoint disrupting the best positives. Communications: how to best exploit them? Who? How? Examining different stakeholders? External and internal? Citizens?"

These quotes demonstrate that researching $\mathrm{CBE}$ requires diverse stakeholder perspectives because stakeholders cannot be categorized as a whole but as discrete groups with equal relevance to a country's brand (i.e., image and/or reputation). Thus, we conclude that a country name does add value to or subtract value from its country brand equity, as remarked by Aaker (1991), Kotler and Gertner (2002), Papadopoulos and Heslop (2002), and Mariutti and Giraldi (2019).

\section{Restructuring brand equity into country brand equity}

Before proceeding with the presentation of our proposal for a CBE framework, it is relevant to elucidate the analytical process in order to determine whether (a) the verbal data were conceptually linked to the theory; (b) the dataset (interviewee responses) was within the respective dimensions that form CBE. In line with Aaker's (1991, 1992), Keller's (1993), and Yoo and Donthu's (2001) fundamental conceptualizations of brand equity, the sample is compliant in this regard. Thus, in light of the literature reviewed, Table 2 indicates seven brand equities and specific dimensions of brand equity aligned with country-oriented settings after being categorized and documented by the authors for this current study. It is relevant to register that Aaker's (1991; 1992) and Keller's $(1993 ; 1998)$ classical principles were also pondered besides the theoretical supported indicated.

\section{Table 2}




\section{Seven dimensions of country brand equity}

\begin{tabular}{|c|c|c|}
\hline Dimensions of CBE & Interviewees' support & Theoretical support \\
\hline $\begin{array}{l}\text { 'country brand } \\
\text { reputation' }\end{array}$ & $\begin{array}{l}\mathrm{E} 2, \mathrm{E} 4, \mathrm{E} 6, \mathrm{E} 7, \mathrm{E} 8, \mathrm{E} 10 \\
\mathrm{E} 11, \mathrm{E} 12, \mathrm{E} 13, \mathrm{E} 15, \text { and } \\
\mathrm{E} 17\end{array}$ & $\begin{array}{l}\text { Foroudi et al., 2016; Foroudi et al., 2018; Jurisic and Azevedo, 2011; } \\
\text { Mariutti, 2017; Mariutti and Giraldi, 2019; Passow et al., 2005; }\end{array}$ \\
\hline 'country brand Image' & $\begin{array}{l}\mathrm{E} 2, \mathrm{E} 4, \mathrm{E} 6, \mathrm{E} 7, \mathrm{E} 8, \mathrm{E} 9, \\
\mathrm{E} 10, \mathrm{E} 12, \mathrm{E} 14, \mathrm{E} 15, \mathrm{E} 16, \\
\text { and } \mathrm{E} 17\end{array}$ & $\begin{array}{l}\text { Foroudi et al., 2016; Foroudi et al., 2018; Giraldi, 2016; Kotler et al., } \\
\text { 1993; Kotler and Gertner, 2002; Mariutti, 2017; Pappu and Quester, } \\
\text { 2010; Zeugner-Roth et al., } 2008\end{array}$ \\
\hline $\begin{array}{l}\text { 'country brand } \\
\text { associations' }\end{array}$ & $\begin{array}{l}\mathrm{E} 1, \mathrm{E} 2, \mathrm{E} 3, \mathrm{E} 5, \mathrm{E} 6, \mathrm{E} 7 \\
\mathrm{E} 9, \mathrm{E} 11, \mathrm{E} 12, \mathrm{E} 13, \mathrm{E} 15 \\
\mathrm{E} 16, \text { and } \mathrm{E} 17\end{array}$ & $\begin{array}{l}\text { Bose et al., 2020; Chatzipanagiotou et al., 2016; Davcik et al., 2015; } \\
\text { Foroudi et al., 2016; Giraldi, 2016; Kotler et al., 1993; Kotler and } \\
\text { Gertner, 2002; Mariutti, 2017; Pappu et al., 2006, Pappu and } \\
\text { Quester, 2010; Veloutsou et al., 2013; Zenker, 2014; Zeugner-Roth } \\
\text { et al., } 2008\end{array}$ \\
\hline $\begin{array}{l}\text { 'country brand } \\
\text { awareness' }\end{array}$ & $\mathrm{E} 2, \mathrm{E} 4, \mathrm{E} 5, \mathrm{E} 14$, and E15 & $\begin{array}{l}\text { Foroudi et al., 2018; Kotler and Gertner, 2002; Pappu and Quester, } \\
\text { 2010; Zeugner-Roth et al., 2008; }\end{array}$ \\
\hline ‘country brand loyalty’ & $\mathrm{E} 6, \mathrm{E} 7, \mathrm{E} 8$, and E15 & Pappu and Quester, 2010; Zeugner-Roth et al., 2008 \\
\hline $\begin{array}{l}\text { 'country brand } \\
\text { perceived quality' }\end{array}$ & $\mathrm{E} 1, \mathrm{E} 6, \mathrm{E} 7$, and $\mathrm{E} 15$ & Pappu and Quester, 2010; Zeugner-Roth et al., 2008 \\
\hline 'channel relationships' & $\begin{array}{l}\mathrm{E} 1, \mathrm{E} 2, \mathrm{E} 3, \mathrm{E} 4, \mathrm{E} 5, \mathrm{E} 6 \\
\mathrm{E} 9, \mathrm{E} 10, \mathrm{E} 11, \mathrm{E} 15, \text { and } \\
\mathrm{E} 16\end{array}$ & $\begin{array}{l}\text { Jurisic and Azevedo, 2011; Kotler et al., 1993; Kotler and Gertner, } \\
\text { 2002; Mariutti, 2017; Pappu and Quester, } 2010 \text { Seo, 2013; Warnaby } \\
\text { and Medway, } 2013\end{array}$ \\
\hline
\end{tabular}

As shown in Table 2, our study not only goes beyond previous studies on brand equity by incorporating 'brand reputation' into a country level, but also does so by examining the interrelationships between 'brand image' and 'brand reputation' (Figure 1) throughout stakeholders' perspectives (not only consumers but any type of stakeholder). Considering the dimensions of brand equity described above, both Aaker's and Keller's views were customeroriented and emphasize these dimensions' importance for products. Nevertheless, we pay closer attention to the literature regarding these seven dimensions (Table 2) for expanding knowledge on the conceptualization of $\mathrm{CBE}$ and proposing an original framework systematically incorporating them, as explained next.

\section{CBE dimensions}

Considering the above and the particular outcomes from the inquiry to the sample ('Based on your understanding, what are the differences or similarities between both terms - 'country image' and 'country reputation' in a country's brand context?'), we attempt to answer our research question - 'How are country image and country reputation in a country's brand context conceptualized in extant research?'

Therefore, we propose a seven-dimensional CBE framework (Figure 1) that emerged contextually and analytically from the interviews to fill this gap in the literature and advance the state of the art of the conceptualization of country brand equity. To do so, we considered the two core constructs (country brand image and country brand reputation) at the top right and left sides of the framework, plus the five original dimensions (country brand associations, country brand

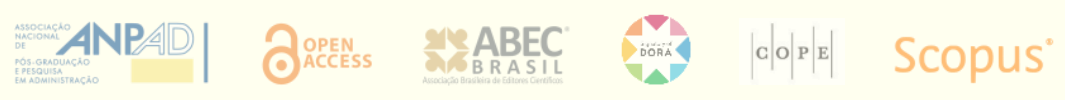


awareness, country brand loyalty, country brand perceived quality, and channel relationships). These emerged from the analysis as they recurred throughout the dataset and from the literature (Table 2), thus completing the CBE heptagonal multidimensional model. These seven dynamic dimensions identified in the interviews are conceptually intertwined and need to be better explored in future studies regarding their interrelationships.

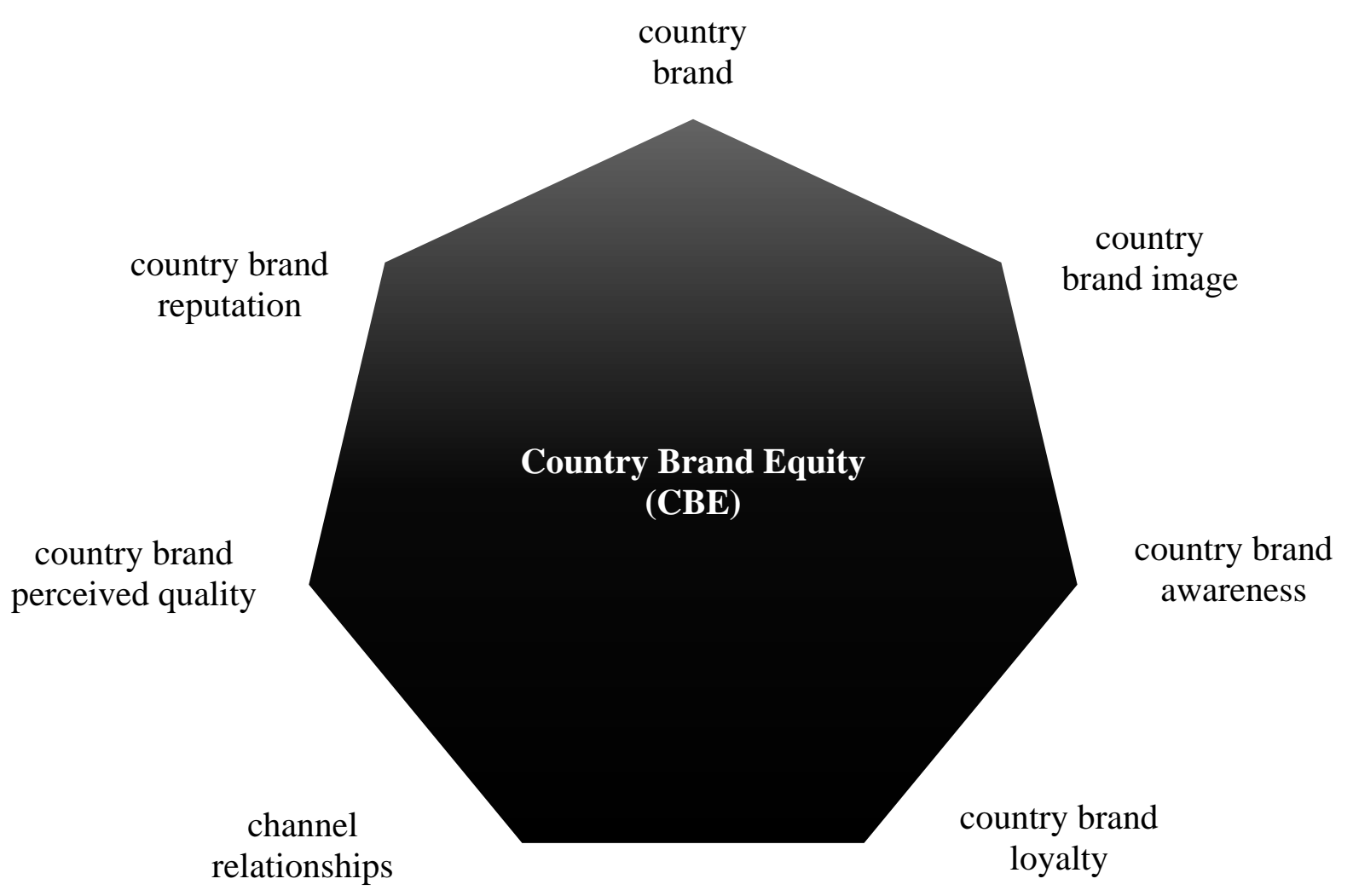

Figure 1. The visual seven-dimensional CBE framework

This model is, therefore, driven by the interview findings and is a substantial complement to the previous intensive literature review - particularly regarding the inclusion of 'reputation' as an added construct of CBE. This rationale is confirmed by several quotes from the interviews (Table 1). Indeed, the interviews not only follow the dominant literature regarding the definition of each dimension but also present possible connections existing among them (Aaker, 1992; de Chernatony, 1999; Fill, 2013; Fombrun, 1997; Kapferer, 1992; Keller, 1993). Conceptual comparisons between the literature review and the empirical evidence also help us to clarify the mutual influence of both contributors of country brand equity.

Thus, this contemporary conceptual paper seeks to propose an alternative conceptualization of brand equity that could add 'reputation' as a driven force towards the value of a place brand (country, region, or city) and engender a debate for further research. Another significant finding to emerge from this study is that studies on CBE need to examine more closely the empirical 
linkages between country brand reputation and country brand image. Country brand image and country brand reputation are core constructs of CBE that are both influenced by the theoretical fundamentals and categorized dimensions, as demonstrated with our proposed framework in Figure 1.

\section{Country brand image and country brand reputation}

By calling attention to the terminologies of our seven-dimensional framework (Figure 1), CI and $\mathrm{CR}$, as two dynamic constructs of CBE, we refer to them henceforth as country brand image $(\mathrm{CBI})$ and country brand reputation $(\mathrm{CBR})$, as recognized during the coding stage. These dimensions came up after the theoretical and analytical arrangement between the understanding of the constructs based on the literature and the experts' data. Furthermore, a few interviewees touched on the influential linkage between image and reputation concerning CBE (i.e., that CBI is a part of the CBR), thus confirming the previous research (Mariutti, 2017; Mariutti \& Giraldi, 2019; Passow et al., 2005). Our model conceptually demonstrates the following constructs: Country brand image is a key element of the reputation of a country and is founded on spontaneous understandings, while CBR functions as a robust construct with a dense understanding of the country brand.

\section{Country brand associations}

Brand associations (Aaker, 1991; Keller, 1993, 1998) with a country refer to anything linked in memory to a country's brand in a meaningful way (Aaker, 1991; Keller, 1993, 1998) as being favorable (desirable and deliverable), strong (relevant and consistent), and unique (Keller, 1993; 1998). As such, country brand associations may expand 'directions' towards the value of the country (Pappu \& Quester, 2010), given that country image is a set of associations organized in a meaningful way (Keller, 1993; Kapferer, 1992), with potential negative short- and long-term consequences (Papadopoulos \& Heslop, 2002). Both the reputation and the image of a country are related to brand knowledge (Keller, 1993, 1998) and formed by latent associations with country brand equity. Moreover, for instance, the literature is in agreement that brand equity can be assessed through poll items based on the country's perceived value of associations (Aaker, 1991; Keller, 1993) based on current debates on place brand equity (Foroudi et al., 2016). Brand associations play a key antecedent role in brand equity (Pappu et al., 2006; Veloutsou et al., 2013; Yoo \& Donthu, 2001). E9 stated that 'country brand associations are very important,' in agreement with Chatzipanagiotou et al. (2016). Through the power of branding, a country makes people aware of the location and then seeks to link desirable associations with it (Keller 1998). Moreover, the previous research has shown that in terms of specifying stakeholder involvement and communication channels (Kotler \& Gertner, 2002; Warnaby \& Medway, 2013), conceptualizing $\mathrm{CBE}$ requires establishing the country brand identity intended to create favorable, strong, and unique brand associations with the country (Keller, 1993, 1998). Country brand associations help process or retrieve information (Aaker, 1992) and are informational memories that contain the essence of the country brand (Keller, 1998), whether related to experiences or not. Monitoring country brand associations relies on Keller's principles of brand 
associations, and CBE involves authenticating meaningful (immediate, temporary, or fixed) mental associations or experiences with the country itself. Once again, this leads to the need for one or more studies of brand equity from stakeholder perspectives (Davcik et al., 2015).

\section{Country brand awareness}

Given the foregoing, country brand awareness indicates the ability of stakeholders to recognize and/or recall the country brand and its features (Aaker, 1991; Keller, 1993); without awareness of a country, stakeholders are unable to have perceptions of quality, associations, or loyalty towards the country (Foroudi et al., 2016; Pappu \& Quester, 2010) for recognition (after recognizing, stimulates the need) and for recall (the need arises after remembering) as endorsed by Keller (1993) and authors cited in Table 2, from a place brand perspective. Continuously building brand awareness is required to enhance brand equity, and the same happens at the country level.

\section{Country brand loyalty}

Loyal stakeholders and their continual and devoted relationships within the country are required to perceive behavioral movements of loyalty towards the country and its products (Aaker, 1992; Foroudi et al., 2016; Giraldi, 2016; Pappu \& Quester, 2010).

\section{Country brand perceived quality}

Perceived quality of country brand refers to stakeholder perceptions of the overall quality or superiority of a country's brand (Chatzipanagiotou et al., 2016) with respect to a given purpose (Aaker, 1991; Keller, 1993, 1998; Selnes, 1993) compared with other countries (Zeugner-Roth et al., 2008); perceived quality is an effective tool in the context of strong international competition and is reason enough for consumers to buy from a country (Aaker, 1991).

\section{Channel relationships}

Channel relationships as a property asset of CBE can provide a strong competitive advantage, characterized as marketing actions resulting from knowledge relationships (Aaker, 1991, 1992) with existing or potential stakeholders' relationships to create value and market a country's brand. In this context, there are several forms of brand-building communications, such as marketing communications, public relations, advertising, social media, media, storytelling, and relationship building. 


\section{Proposition for a seven-dimensional CBE framework}

As illustrated in Figure 1, the seven-dimensional CBE framework, the CBE construct is composed of two core dimensions (i.e., CBR and CBI) together with country brand associations, country brand awareness, country brand loyalty, country brand perceived quality, and channel relationships.

Nevertheless, CBR and CBI comprise robust conceptual specific characteristics regarding the corresponding type and scope, as well as the nature of their country brand associations.

Country brand reputation is characterized by generally agreed perceptions, and the types of stakeholders are positioned as internal- and external-oriented along with essential characteristics called value drivers. Value drivers include 'long-term' 'phenomena'; 'solid and sustained set of images'; 'rational-attributed and attentive-linked'; 'experience-related and highly intangible'; 'global dimension-measured'; 'both primary and secondary data'; 'score-ranked'; and a 'good or bad reputation'. However, CBI is characterized by fragmented perceptions and the types of stakeholders are positioned as external-oriented along with several value drivers: 'immediate though't; 'temporary'; 'pictorial and symbolic descriptions'; 'physical-attributed and event-linked'; 'mental-oriented and tangible/intangible'; 'multidimensional-measured'; 'market- and sectorbased'; 'mostly primary data'; and 'positive/negative image'.

Thus, the seven-dimensional CBE framework was developed under two interpretations: the 'share of mind' related to the image of a country and the 'share of experience' related to the reputation of a country. Hence, the model reinforces the methodological importance of measuring more subjective indicators (related to the image of a country) and more objective indicators (related to the reputation of a country). Both are conceptually predetermined when conceptualizing CBE as two detached constructs aggregating shared evidence and creating mutual value for a country's brand equity. However, the reputation of a country theoretically embraces the country's image, as illustrated in the speech of E7:

"In a way, to me these two are overlapping;" yet, "there is a reasonably clear cut between these two concepts."

Therefore, the model demonstrates that each construct is described by several consistent features that are interrelated with each other and with CBE through country brand associations when perceived from specific stakeholder's perspectives. At least eight features regarding the value drivers of each construct are presented in our framework (Figure 1). Such features emerged from the literature and the data analysis as key characteristics of each of their roles as contributors to country brand equity - CBR and CBI. Nevertheless, the country brand associations as an antecedent condition thoroughly frame the CBI as an immediate thought (subjective scheme), converting stronger associations into a CBR as a long-term phenomenon (objective scheme). Figure 1 shows the alignments of the value drivers with each construct, as a country's brand represents a multidirectional conceptualization (Veloutsou \& Guzmán, 2017). 
This paper offers an alternative approach for systematically estimating country brand equity, under a methodological branding perspective whereby the image of a country can be measured by subjective indicators and the reputation of a country can be measured by objective indicators. Measurement can be done systematically using previous scales for measuring CBE (Bose et al., 2020; Mariutti \& Giraldi, 2019; Pappu et al., 2006; Pappu \& Quester, 2010; Zenker, 2014; Zeugner-Roth et al., 2008).

Studies on CBE require continuous interpretations of CBR and CBI as core constructs of country brand equity, which are perceptually driven by the value drivers. Furthermore, acknowledging that CBR is a key construct of the CBE parallels Papadopoulos and Hamzaoui-Essoussi's view (2015) that CBR and image are fundamental and robust constructs for revealing country brand equity. Interestingly, fluctuations about a CBI or CBR may or may not affect all stakeholders (Kapferer, 1992), because the features of the value drivers of these two constructs of CBE are more complex and multidirectional than those of a product or a service. The results complement those of Zeugner-Roth et al. (2008) and Pappu and Quester (2010), who have statistically analyzed Aaker's CBBE model (1991) and Keller's concepts (1993) when developing their models of country brand equity.

\section{CONCLUSIONS}

According to the above discussion, we conceptualize CBE by conceiving these two combined constructs - brand image and brand reputation - as substantial pillars with leading-edge interpretations, albeit previously overlooked in the existing literature on brand equity and country brand equity. We suggest this foremost model for the development of original approaches to place brand equity. Although previous evidence regarding CBE dimensionality is shown as multidimensional (Mariutti \& Giraldi, 2019; Papadopoulos \& Heslop, 2002, 2003; Pappu et al., 2006; Pappu \& Quester, 2010; Zeugner-Roth et al., 2008), we argue that a seven-dimensional CBE framework constructed from qualitative counterpart research promotes two new variables: $\mathrm{CBI}$ and $\mathrm{CBR}$.

This study developed the seven-dimensional CBE framework by analytically endorsing new theoretical interrelationships of two constructs (CBR and CBI) for advancing the conceptualization of $\mathrm{CBE}$ within the international business and international marketing disciplines. More importantly, 'reputation' is scientifically recognized as an additional construct of place brand equity. We can affirm that our previous definition of CBE was confirmed and substantially expanded by strengthening the existing theory on CBE in terms of conceptual linkages and contextual implications of both constructs throughout the interviewees' contributions. Our present study is the first study to empirically explore the conceptualization of CBE using in-depth knowledge from interviews as rich qualitative data to provide new understandings and a robust explanation of the constructs of country brand equity.

Another contribution of the present study is the confirmation of the importance of country brand associations from a wide-ranging knowledge based on the classical and fundamental constructs of $\mathrm{CBE}$ in terms of constructing the value of the country brand. This model proposition was 
based mostly on the existing literature and corroborated by the experts' knowledge. This sample indicated that reputation and image in the context of a country's brand are core constructs, yet the reputation of a country evidently comprises the image of a country. Moreover, this proposition is elaborated by the theoretical assumption that the indicators listed for both constructs can be used not only to conceptualize CBE but also to apply a scale measurement instrument (Mariutti \& Giraldi, 2019).

Hence, theoretical and methodological directions are anticipated by expertly measuring CBE using CBI and CBR. As demonstrated previously by the data analysis, a solid and theoretically focused qualitative approach was adopted. Furthermore, the seven-dimensional CBE framework was created from consistent and comprehensive results that originated from each participant's knowledge and from the pre-existing literature (Foroudi et al., 2016; Mariutti, 2017; Papadopoulos \& Heslop, 2002; Pappu \& Quester, 2010; Zeugner-Roth et al., 2008).

Hence, our definition for country brand equity, which is based on this study: 'CBE indicates the value added and the overall assessment of stakeholder perceptions originated from country brand associations attached to the reputation of the country and the image of the country, in conjunction with country brand awareness, country brand loyalty, country brand perceived quality, and channel relationships'. The concept of brand equity included in this current study has been studied in branding and marketing and been applied to firms, products, and services. However, no research has explored how researchers respond theoretically to the complexity of the value of a country's brand; therefore, the terms 'brand image' and 'brand reputation' must be reassessed, as recommended by Suddaby (2010), in order to strengthen the constructs upon which the theory is based.

Rethinking the state of the art of the conceptualization of country brand equity, these conclusions contribute both to the theory and the practice by clarifying two main aspects of CBE. First, the study resourcefully elucidates the conceptualization of CBE by pointing out two overlooked perceptual components. Second, this study clarifies how the image of a country and the reputation of a country can be contributors to the conceptualization of CBE in terms of considering their mutual interrelationships. Combined, these insights offer researchers and professionals a better understanding of the conceptualization of CBE when planning their marketing and branding initiatives.

As a forward-thinking domain, $\mathrm{CBE}$ is a relevant area for governments to harness in order to develop bold country brand identities to communicate to their stakeholders to foster country brand equity. Investments in country branding campaigns for maximizing CBE are required for all countries. A positive country image linked to a good reputation can be a significant driver of long-term competitive development for a country, while a negative image can jeopardize the value of a country's brand.

Henceforward, both the visual seven-dimensional CBE framework (Figure 1) and the seven main dimensions of CBE (Table 2) not only represent a significant paradigm shift for CBE theory but also represent a noteworthy contribution to the literature in international business, marketing, 
and branding. Additionally, this study has demonstrated, for the first time, that CBI and CBR complement our understanding of country brand equity, which is conveyed by the nature of country brand associations, by the stakeholders' perspectives, and by the features of value drivers. This model is adaptable to any country, region, city, or place (e.g., neighborhood, university, airport, square, or museum) to structure strong place brand equity and to support substantial development in emergent and emerging locations and markets.

Regarding the theoretical contributions, this research offers research insights for marketing scholars and governmental offices that aim to systematically study place brand equity. The main contribution of our interpretative research concerns the incorporation of 'reputation' into the brand equity construct at a country level. Moreover, future work could estimate brand equity by measuring the value of a place (country, region, or city) by investigating place brand reputation as a multidimensional construct containing the main dimensions of country brand equity. We also recommend that research on CBE focus on additional variables of a country's brand, to represent each country's particularities and cross-national research among countries.

This study calls for further research to consider the roles of brand image and brand reputation on the conceptualization of place brand equity (e.g., country, region, city, or any other place category). Place brand equity studies require authentic contextual frameworks to explore the value of a place brand by examining the complexity of the two latter constructs (Figure 1). Additionally, the seven dynamic dimensions of the proposed framework require further investigations given the complex nature of their theoretical interactions. Another recommendation is related to the need for a practice-oriented approach aiming to identify and tackle specific stakeholders' perceptions by systematically applying our model in terms of managing a place brand value. Finally, we suggest developing business plans for target segmentation and integrated participation designed to manage the reputation of a place in terms of attracting investment, residents, tourists, inter alia. Furthermore, public sector participation is also required to foster the joint efforts of professionals and governmental policies on the economic performance of a nation's prosperity. For future studies, we recommend a quantitative approach to validate these inductive empirical outcomes.

The most important limitation lies in the fact that a quantitative approach based on scales is required for the statistical legitimacy of the proposed model. Additionally, the diversity of stakeholders' groups involved with country brand was low and could be remedied by including internal stakeholders such as citizens, residents, immigrants, refugees, expatriates, students, government, national markets, etc.; similarly, external stakeholders could include tourists, potential investors, global markets, international authorities, international media, etc.

\section{Acknowledgments}

Many thanks to the reviewers and the interviewees of this study for their participation.

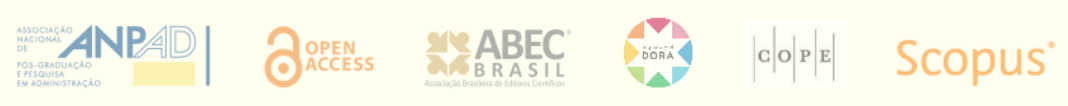




\section{Funding}

Fundação de Amparo à Pesquisa do Estado de São Paulo (FAPESP) 2016/18247-0.

\section{REFERENCES}

Aaker, D. A. (1991). Managing Brand Equity. Capitalizing on the Value of a Brand Name. New York: The Free Press.

Aaker, D. A. (1992). The Value of Brand Equity. Journal of Business Strategy, 13(4), 27-32. https://doi.org/10.1108/eb039503

Bastos, W., \& Levy, S. J. (2012). A history of the concept of branding: Practice and theory. Journal of Historical Research in Marketing, 4(3), 347-368. https://doi.org/10.1108/17557501211252934

Bose, S., Roy, S. K., Alwi, S. F. S., \& Nguyen, B. (2020). Measuring customer-based place brand equity (CBPBE) from a public diplomacy perspective: Evidence from West Bengal. Journal of Business Research. 116, 734-744. https://doi.org/10.1016/j.jbusres.2018.01.059

Chatzipanagiotou, K., Veloutsou, C., \& Christodoulides, G. (2016). Decoding the complexity of the consumer-based brand equity process. Journal of Business Research. 69(11), 5479-5486. https://doi.org/10.1016/j.jbusres.2016.04.159

Davcik, N. S., Silva, R. V., da, \& Hair, J. F. (2015) Towards a unified theory of brand equity: Conceptualizations, taxonomy and avenues for future research. Journal of Product EF Brand Management, 24(1), 3-17. https://doi.org/10.1108/JPBM-06-2014-0639

de Chernatony, L. (1999). Brand management through narrowing the gap between brand identity and brand reputation. Journal of Marketing Management, 15(1-3), 157-179. https://doi.org/10.1362/026725799784870432

Foroudi, P., Jin, Z., Gupta, S., Foroudi, M. M., \& Kitchen, P. J. (2018). Perceptional components of brand equity: Configuring the symmetrical and asymmetrical paths to brand loyalty and brand purchase intention. Journal of Business Research, 89, 462-474. https://doi.org/10.1016/j.jbusres.2018.01.031

Foroudi, P., Gupta, S., Kitchen, P., Foroudi, M. M., \& Nguyen, B. (2016). A framework of place branding, place image, and place reputation: Antecedents and moderators. Qualitative Market Research: An International Journal, 19(2), 241-264. https://doi.org/10.1108/QMR-02-2016-0020

Fill, C. (2013). Marketing communications: Brands, experiences and participation. Essex: Pearson.

Flick, U. (2014). An introduction to qualitative research (5 $\left.5^{\text {th }} \mathrm{ed}\right)$. London: SAGE.

Fombrun, C. J. (1997). The Reputational Landscape. Corporate Reputation Review, 1, 5-13. https://doi.org/10.1057/palgrave.crr.1540024

Giraldi, J. M. E. (2016) Evaluation of the impact of Brazil's sustainability on the behavioral intentions of stakeholders toward the country. Evaluation and Program Planning, 54, 135-143. https://doi.org/10.1016/j.evalprogplan.2015.07.007

Hair, J., Wolfinbarger, M., Ortinau, D.J. \& Bush, R.P. (2010) Essentials of Marketing Research. Boston: McGraw-Hill.

Jurisic, B., \& Azevedo, A. (2011) Building customer - brand relationships in the mobile communications market: The role of brand tribalism and brand reputation. Journal of Brand Management, 18(4-5), 349-366. https://doi.org/10.1057/bm.2010.37

Kapferer, J. N. (1992). Strategic brand management: New approaches to creating and evaluating brand equity. Kogan Page: London.

Keller, K. L. (1993). Conceptualizing, measuring, and managing consumer-based brand equity. Journal of Marketing, 57(1), 1-22. https://doi.org/10.2307/1252054

Keller, K. L. (1998). Strategic Brand Management. Upper Saddle River, NJ: Prentice Hall. 
Kotler, P. \& Gertner, D. (2002). Country as brand, product, and beyond: A place marketing and brand management perspective. Journal of Brand Management, 9(4), 249-261. https://doi.org/10.1057/palgrave.bm.2540076

Kotler, P., Haider, D., \& Rein, I. (1993). Marketing places: Attracting investment, industry, and tourism to cities, states, and nations. New York: The Free Press.

Kotler, P., \& Levy, S. J. (1969). Broadening the concept of Marketing. Journal of Marketing, 33(1), 10-15. http://doi.org/10.2307/1248740

Mariutti, F. G. (2017). The placement of country reputation towards place management. Journal of Place Management and Development, 10 (3), 240-253. http://doi.org/10.1108/JPMD-10-2016-0067

Mariutti, F. G., \& Giraldi, M. E. J. (2019). How does a brand reputation-driven construct impact on country brand equity? A Cross-National study of Brazil and China. Journal of International Consumer Marketing, 31(5),1-20. https://doi.org/10.1080/08961530.2019.1590280

Papadopoulos, N., \& Hamzaoui-Essoussib, L. (2015). Place images and nation branding in the African context: Challenges, opportunities, and questions for policy and research. African Journal of Management, 1(1), 1-24. https://doi.org/10.1080/23322373.2015.994423

Papadopoulos, N., \& Heslop, L. A. (2002). Country equity and country branding: Problems and prospects. Journal of Brand Management, 4(5), 294-314. https://doi.org/10.1057/palgrave.bm.2540079

Papadopoulos, N., \& Heslop, L. A. (2003). Country equity and product-country images: state-of-the-art in research and implications. Handbook of Research in International Marketing, 402-403. https://doi.org/10.4337/9781781950395.00032

Pappu, R., \& Quester, P. G. (2010). Country equity: Conceptualization and empirical evidence. International Business Review, 19(3), 276-291. https://doi.org/10.1016/j.ibusrev.2009.12.006

Pappu, R., Quester, P. G., \& Cooksey, R. W. (2006). Consumer-based brand equity: improving the measurement - empirical evidence. European Journal of Marketing, 40(5-6), 696-717. https://doi.org/10.1108/10610420510601012

Passow, T., Fehlmann R., \& Grahlow H. (2005). Country reputation - from measurement to management: The case of Liechtenstein, corporate reputation review, 7, 309-326. https://doi.org/10.1057/palgrave.crr.1540229

Roth, K. P., \& Diamantopoulos, A. (2009). Advancing the country image construct. Journal of Business Research, 62(7), 726-740. https://doi.org/10.1016/j.jbusres.2008.05.014

Selnes, F. (1993). An examination of the effect of product performance on brand reputation, satisfaction and loyalty. European Journal of Marketing, 27(9), 19-35. https://doi.org/10.1108/03090569310043179

Seo, H. (2013). Online social relations and country reputation. International Journal of Communication, 7, 1-20. Retrieved from https://ijoc.org/index.php/ijoc/article/view/1926/887

Steenkamp, J. B. (2017). Global brand strategy: World-wise Marketing in the age of branding. London: Palgrave Macmillan.

Suddaby, R. (Ed.). (2010). Editor's comments: Construct clarity in theories of management and organization. Academy of Management Review, 35(3), 346-357. Retrieved from http://cmsdev.aom.org/uploadedFiles/Publications/AMR/SuddabyEditorCommentsConstruct.pdf

Veloutsou, C., Christodoulides, G., \& Chernatony, L., de. (2013). A taxonomy of measures for consumerbased brand equity: drawing on the views of managers in Europe. Journal of Product $\mathcal{E}$ Brand Management, 22(3), 238-248. https://doi.org/10.1108/JPBM-02-2013-0256

Veloutsou, C., \& Guzmán, F. (2017). The evolution of brand management thinking over the last 25 years as recorded in the Journal of Product \& Brand Management. Journal of Product \& B Brand Management, 26(1), 2-12. https://doi.org/10.1108/JPBM-01-2017-1398

Warnaby, G., \& Medway, D. (2013). What about the 'place' in place marketing? Marketing Theory, 13(3), 345-363. https://doi.org/10.1177/1470593113492992

Zavattaro, S. M., Daspit, J. J., \& Adams, F. G. (2015). Assessing managerial methods for evaluating place brand equity: A qualitative investigation. Tourism Management, 47, https://doi.org/10.1016/j.tourman.2014.08.018

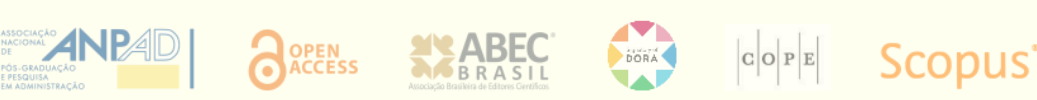


Zenker, S. (2014). Measuring place brand equity with the advanced Brand Concept Map (aBCM) method. Place Branding and Public Diplomacy, 10 (2), 158-166. https://doi.org/10.1057/pb.2014.2

Zeugner-Roth, K., Diamantopoulos, A., \& Montesinos, M. A. (2008). Home country image, country brand equity and consumers' product preferences: An empirical study. Management International Review, 48(5), 577-602. https://doi.org/10.1007/s11575-008-0031-y

Yoo, B., \& Donthu, N. (2001). Developing and validating a multidimensional consumer-based brand equity scale. Journal of Business Research, 52(1), 1-14. https://doi.org/10.1016/S0148-2963(99)00098-3

Yadav, M. S. (2014). Enhancing theory development in marketing. Academy of Marketing Science Review, 4(1), 1-4. http://doi.org/10.1007/s13162-014-0059-z

\section{Author contributions}

$1^{\text {st }}$ author: conceptualization (lead), data curation (lead), formal analysis (equal), funding acquisition (equal), project administration (equal), writing-original draft (lead), writing-review $\&$ editing (equal).

$2^{\text {nd }}$ author: conceptualization (supporting), funding acquisition (equal), resources (supporting), writing-review $\&$ editing (supporting).

\section{Authors}

\section{Fabiana Gondim Mariutti*}

Universidade de São Paulo, Faculdade de Economia, Administração e Contabilidade de Ribeirão Preto

Av. Bandeirantes, 3900, Vila Monte Alegre, 14040-905, Ribeirão Preto, SP, Brazil

Universidade Positivo, Business School

Rua Prof. Pedro Viriato Parigot de Souza, 5300, Campo Comprido, 81280-330, Curitiba, PR, Brazil

famariutti@yahoo.com.br

iD https://orcid.org/0000-0003-2404-7041

\section{Janaina de Moura Engracia Giraldi}

Universidade de São Paulo, Faculdade de Economia, Administração e Contabilidade de Ribeirão Preto

Av. Bandeirantes, 3900, Vila Monte Alegre, 14040-905, Ribeirão Preto, SP, Brazil

jgiraldi@usp.br

(iD) https://orcid.org/0000-0003-3086-7134

* Corresponding author

Peer review is responsible for acknowledging an article's potential contribution to the frontiers of scholarly knowledge on business or public administration. The authors are the ultimate responsible for the consistency of the theoretical references, the accurate report of empirical data, the personal perspectives, and the use of copyrighted material.

This content was evaluated using the double-blind peer review process. The disclosure of the reviewers' information on the first page is made only after concluding the evaluation process, and with the voluntary consent of the respective reviewers. 


\section{APPENDIX I - QUALITATIVE DATA}

\section{Table A1}

\section{Interviewees' profiles}

\begin{tabular}{|c|c|c|c|}
\hline Interviewee & Academic position and expertise & $\begin{array}{l}\text { Country of origin and } \\
\text { country of work }\end{array}$ & Data and length \\
\hline Expert 1 & Senior Lecturer in Tourism Marketing & England & $\begin{array}{l}\text { July } 18^{\text {th }} \\
\qquad 43^{\prime}\end{array}$ \\
\hline Expert 2 & Lecturer in Tourism, Events, and Hospitality & England & $\begin{array}{c}\text { July } 20^{\text {th }} \\
51^{\prime}\end{array}$ \\
\hline Expert 3 & $\begin{array}{c}\text { Director of Studies and Professor in } \\
\text { Communication }\end{array}$ & England & $\begin{array}{l}\text { July } 25^{\text {th }} \\
32^{\prime}\end{array}$ \\
\hline Expert 4 & $\begin{array}{c}\text { Senior Lecturer in Marketing and Head of the } \\
\text { Faculty }\end{array}$ & $\begin{array}{l}\text { Greece } \\
\text { England }\end{array}$ & $\begin{array}{c}\text { July } 26^{\text {th }} \\
34^{\prime}\end{array}$ \\
\hline Expert 5 & Senior Lecturer in Marketing & $\begin{array}{l}\text { Uruguay } \\
\text { England }\end{array}$ & $\begin{array}{l}\text { August } 3^{\text {rd }} \\
38^{\prime} 06^{\prime \prime}\end{array}$ \\
\hline Expert 6 & Senior Lecturer in Marketing & $\begin{array}{l}\text { Spain } \\
\text { England }\end{array}$ & $\begin{array}{l}\text { August } 3^{\text {rd }} \\
2^{\prime}\end{array}$ \\
\hline Expert 7 & Senior Lecturer in Marketing & $\begin{array}{l}\text { China } \\
\text { England }\end{array}$ & $\begin{array}{l}\text { August } 14^{\text {th }} \\
\text { 1h } 04^{\prime} 15^{\prime \prime}\end{array}$ \\
\hline Expert 8 & Associate Professor in Marketing & $\begin{array}{l}\text { Germany } \\
\text { Denmark }\end{array}$ & $\begin{array}{l}\text { August } 17^{\text {th }} \\
19^{\prime} 30^{\prime \prime}\end{array}$ \\
\hline Expert 9 & Senior Lecturer in Brand Communication & England & $\begin{array}{l}\text { September } 6^{\text {th }} \\
27^{\prime} 13^{\prime \prime}\end{array}$ \\
\hline Expert 10 & Lecturer in International Marketing & $\begin{array}{l}\text { Greece } \\
\text { England }\end{array}$ & $\begin{array}{l}\text { September } 7^{\text {th }} \\
22^{\prime} 09^{\prime \prime}\end{array}$ \\
\hline Expert 11 & Professor in International Retail Marketing & England & $\begin{array}{l}\text { September } 8^{\text {th }} \\
27^{\prime}\end{array}$ \\
\hline Expert 12 & Lecturer in Place Branding & Canada & $\begin{array}{c}\text { September } 8^{\text {th }} \\
16^{\prime} 24^{\prime \prime}\end{array}$ \\
\hline Expert 13 & Master's Course Director in Marketing & Portugal & $\begin{array}{l}\text { September } 13^{\text {th }} \\
33^{\prime} 51^{\prime \prime}\end{array}$ \\
\hline Expert 14 & $\begin{array}{l}\text { Lecturer in Marketing and } \\
\text { Head of the Faculty }\end{array}$ & Portugal & $\begin{array}{l}\text { September } 18^{\text {th }} \\
48^{\prime} 31^{\prime \prime}\end{array}$ \\
\hline Expert 15 & Post-Doc in Place Branding & $\begin{array}{l}\text { Portugal } \\
\text { Switzerland }\end{array}$ & $\begin{array}{l}\text { September } 22^{\text {nd }} \\
43^{\prime} 09^{\prime \prime}\end{array}$ \\
\hline Expert 16 & $\begin{array}{l}\text { Professor in Communication and Vice-Dean of the } \\
\text { Faculty }\end{array}$ & $\begin{array}{l}\text { Germany } \\
\text { Switzerland }\end{array}$ & $\begin{array}{l}\text { September } 26^{\text {th }} \\
35^{\prime} 01^{\prime \prime}\end{array}$ \\
\hline Expert 17 & Lecturer in Communication & $\begin{array}{l}\text { Chile } \\
\text { England }\end{array}$ & $\begin{array}{l}\text { October } 11^{\text {th }} \\
40^{\prime} 57^{\prime \prime}\end{array}$ \\
\hline
\end{tabular}

